\title{
Eco-Friendly Management of Maize Cyst Nematode, Heterodera zeae on Maize by Use of Botanicals
}

\author{
R.N. Kumhar, B.L. Baheti and B.S. Chandrawat* \\ Department of Nematology, Rajasthan College of Agriculture, MPUAT, Udaipur, India \\ Department of Plant Pathology and Nematology, SKN College of Agriculture, SKNAU, \\ Jobner, India
}

*Corresponding author

\section{A B S T R A C T}

\section{Keywords \\ Botanicals, Heterodera zeae, Calotropis procera, Aloe vera and Euphorbia neriifolia \\ Article Info \\ Accepted: \\ 02 May 2018 \\ Available Online: \\ 10 June 2018}

Maize cyst nematode, Heterodera zeae causes significant losses in Rajasthan due to monocropping of maize, favourable soil type, environmental conditions and ignorance of management practices. Looking to its importance, present investigations were undertaken to find out the efficacy of botanicals viz., Calotropis procera (latex), Aloe vera (jel) and Euphorbia neriifolia (latex) at 1, 2 and 4 per cent w/v as seed treatment against maize cyst nematode, $H$. zeae on maize. Results showed that Calotropis procera at $4 \%$ was found most effective followed by Calotropis procera at 2 per cent and Aloe vera at 4 per cent to enhance the plant growth parameters of maize and to reduce the infection of maize cyst nematode, $H$. zeae.

\section{Introduction}

Maize (Zea mays L.) cultivated under the wide range of agro-climatic conditions all over the world including India. It is primarily cultivated as a kharif crop but presently, it is also being popularized as an important Rabi and summer crop in certain parts of the country depending upon the environmental conditions and irrigation facilities. It is grown for human consumption as it provides high quality of staple food among rural masses. Maize suffers from number of insects and diseases caused by fungus, bacteria and nematodes (Koshy and Swarup, 1971; Mehta et al., 2015). Nematodes also interact with other disease causing agents (pathogens and soil insects) and adversely affect the quantity and quality of maize production. Among nematodes, maize cyst nematode, Heterodera zeae is considered to be the most important nematode pest of maize in India (Kaushal et al., 2007; Meena et al., 2013). Srivastava and Chawla (2005) reported yield losses of maize to the extent of $17-29 \%$ by maize cyst nematode, $H$. zeae in India at varied inoculum levels and soil conditions. Looking to the importance of maize cyst nematode, Heterodera zeae, number of management practices have been developed and included in package of practices on maize, however, work on eco-friendly management of Heterodera 
zeae on maize is lacking. Therefore, to fill this gap of knowledge, present investigations have been proposed to find out eco-friendly management of maize cyst nematode, Heterodera zeae on maize by use of botanicals.

\section{Materials and Methods}

An experiment was carried out at Department of Nematology, MPUAT, Udaipur, under screen house condition to test the efficacy of botanical extracts viz., Aloe vera (jel), Euphorbia neriifolia (latex) and Calotropis procera (latex) as seed treatment applied at 1, 2 and $4 \%$ (w/v) against maize cyst nematode, Heterodera zeae on maize. A treated check (Neem seed kernel at $10 \% \mathrm{w} / \mathrm{w}$ ) and untreated check were also taken for comparison of results. The experiment was laid out using following procedure in completely randomized design and each treatment was replicated five times.

\section{Maintenance of culture}

Heterodera zeae cysts were collected and kept on Baermann's funnel assembly in distilled water with some pieces of fresh maize roots for proper hatching. Freshly hatched larvae thus obtained were inoculated in root zone of maize and plants were maintained in 12 " sized earthen clay pots from which inoculum was used for various experiments.

\section{Sowing}

Earthen clay pots of 6" size were taken and filled with equal quantity of steam sterilized soil. The weighed quantity of seeds treated with 0.1 per cent carbendazim and seed was taken in a beaker and required quantities of botanicals were added and mix thoroughly to provide uniform coating of botanicals over seeds were sown with three seeds of maize (Pratap Makka-3) in each pot and watered regularly. After 7-10 days of germination, one plant in each pot, nearly of equal size was maintained and others were removed carefully without disturbing the one to be maintained. Each experimental pot was tagged properly.

\section{After care}

Care was taken right from sowing till harvest of experiments the crop. To avoid insect damage, spray of malathion $(0.05 \%)$ or imidacloprid 17.8 SL $(0.10 \%)$ were given as and when required. Thinning was done to maintain desired plant population after 7-10 days of germination. Weeding and hoeing was done timely to avoid weeds and to maintain proper aeration in soil. The recommended doses of nitrogenous and phosphatic fertilizers were applied for proper growth of plants. Pots were randomly rotated to eliminate the effect of sun and shade. Irrigation was made as and when required throughout the course of experimentation.

\section{Harvesting}

Harvesting of plants was done after 45 days of sowing. The entire root system along with soil was carefully taken out from pots and kept in water for half an hour. The root system was then gently washed under running tap water to remove all the adhering soil particles. Observations on plant growth parameters viz. shoot length $(\mathrm{cm})$, shoot weight $(\mathrm{g})$, root length $(\mathrm{cm})$ and root weight $(\mathrm{g})$ as well as nematode parameters viz., number of females / $5 \mathrm{~g}$ root, number of cysts / $100 \mathrm{cc}$ soil, number of eggs and larvae / cyst and number of larvae / $100 \mathrm{cc}$ soil were recorded.

\section{Estimation of initial and final soil population (cyst and larvae)}

For estimation of initial soil population, samples collected from the experimental pots were brought to the laboratory and thoroughly 
mixed. 100 cubic centimeter soil was kept in bowl, poured water, stirred thoroughly and passed through 16 and 100 mesh sieves. The catch of sieve was carefully transferred in a beaker and later on a blotting paper and examined under stereoscopic binocular microscope for counting of cysts. The filtrate of 100 mesh sieve was further passed through 200, 325 and 400 mesh sieves (Cobb's sieving and decanting techniques, 1918) and catch of 400 mesh sieve was placed over Baermann's funnel assembly (Christie and Perry, 1951). After 24 hours, the nematode suspension was drawn from the funnel in a beaker and population was counted under microscope.

\section{Results and Discussion}

Limitation in controlling plant parasitic nematodes through chemical and other methods necessitated search for botanicals to reduce nematode population. Botanicals are an effective, economical and environmentally safer means of reducing losses from plant parasitic nematode. It enables the growers to reduce costs of expensive chemicals, their application and numerous mechanical operations for the production of crop. Recently, botanicals have been proved to be best for nematode management. Looking to the attributes, an experiment was conduct to find out suitable plant product for the management of maize cyst nematode, Heterodera zeae on maize. Therefore, in present investigation, different plants extracts viz. Calotropis procera (latex), Aloe vera (jel) and Euphorbia neriifolia (latex) were tested at $1,2,4 \% \mathrm{w} / \mathrm{v}$ to find out their effect on maize cyst nematode, Heterodera zeae on maize. Observations on plant growth and nematode reproduction characters were recorded for interpretation of experimental findings.

Results showed that application of Calotropis procera, Aloe vera and Euphorbia neriifolia enhanced shoot length $(\mathrm{cm})$, shoot weight $(\mathrm{g})$, root length $(\mathrm{cm})$ and root weight $(\mathrm{g})$ on maize infested with $H$. zeae when applied as seed treatment. It has been observed that higher dose of botanicals provide better response with respect to plant growth parameters over the lower dose.

Among various botanicals, maximum shoot length $(116.30 \mathrm{~cm})$ was obtained with Calotropis procera at 4 per cent followed by C. procera at 2 per cent $(114.30 \mathrm{~cm})$ and Aloe vera at 4 per cent $(112.00 \mathrm{~cm})$. Minimum shoot length $(92.40 \mathrm{~cm})$ was recorded with Euphorbia neriifolia when applied at 1 per cent w/v. Similar trend was noticed with respect to shoot weight $(\mathrm{g})$, root length $(\mathrm{cm})$ and root weight $(\mathrm{g})$.

The results of present investigation are in accordance with the findings of previous workers who reported that seed treatment with botanicals improved plant growth in nematode prone areas. Saravanapriya and Shivkumar (2005) observed that seed treatment with the dry powder of $C$. procera resulted in highest seed germination (98\%) and seedling establishment.

Mehta et al., (2015) reported significant increase in plant growth characters of maize when neem, aak and water hyacinth leaves powder was applied at $4 \mathrm{~g} /$ plant as soil amendment infested with Heterodera zeae.

Aak, Calotropis procera exhibited better response against cyst nematode on maize and it may be due to presence of different phonols, enzymes and toxic substances (Calactin, mudarin and Calotropin) which are active constituents of $C$. procera. These may be having major role in enhancing growth of plant directly as well as indirectly and ultimately resulted in better shoot length, shoot weight, root length and root weight of maize as compared to Aloe vera and Euphorbia neriifolia. 


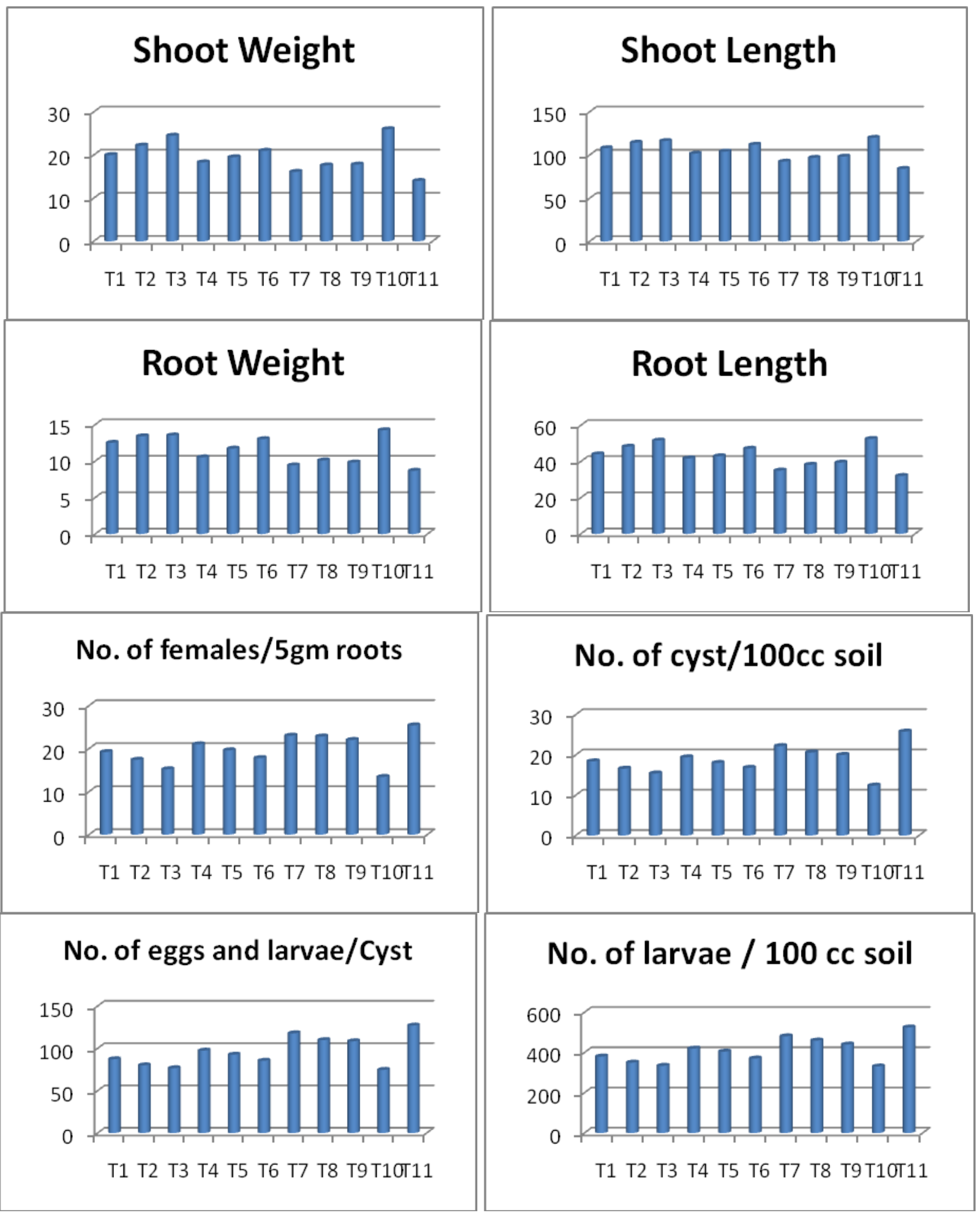

Results showed that application of Calotropis procera, Aloe vera and Euphorbia neriifolia as seed treatment at 1, 2, $4 \%$ effectively reduced number of females $/ 5 \mathrm{~g}$ root, number of cysts/100 cc soil, number of eggs and larvae/cyst and number of larvae/100 cc soil

on maize infested with $H$. zeae. It has been observed that higher dose of botanicals provide good protection from nematode infection over lower dose. Among different treatments, minimum number of females per/5 g root (15.20) was observed with $C$. 
procera at 4 per cent followed by $C$. procera at 2 per cent (17.40) and Aloe vera at 4 per cent (17.80). E. neriifolia (23.00) at 1 per cent was found least effective. Similar trend was obtained with regards to cysts/100 cc soil, eggs and larvae/cyst and final larval population/100 cc soils.

Nematicidal properties of $C$. procera, Aloe vera and Euphorbia neriifolia for the management of phytonematodes on different crops have earlier been reported by number of researchers. Bhardwaj and Trivedi (1999) tested leaf powder of five locally available plants viz., Azadirachta indica, C. procera, Nerium indicuni, Lantana camara and Lowsonia intermis against Heterodera cajani on cowpea and observed that Azadirachta indica, $C$. procera and Lantana camara leaves powder significantly controlled the population of Heterodera cajani. Umamaheswari and Babu (2001) found that Calotropis procera leaf powder at 10 per cent as seed treatment decreased 87.6 and $95.2 \%$ root-knot and reniform nematode population, respectively in cowpea. Venkatesan and Patel (2013) observed that Calotropis procera (1.5 $\% \mathrm{w} / \mathrm{w})$ proved to be more effective in improving plant growth characters, reduced root-knot index and final nematode population of root-knot nematode on bitter gourd.

The suppression of nematodes as seed treatment with plant extracts may be because of the effect of several combined factors. Production of phenols, amino acids and $\mathrm{HCN}$ compound released from plant products, which may have caused inhibitory effect to nematodes. These plant extracts release toxic substances viz., Calactin, mudarin and Calotropin to nematode or enhance activity of predators and parasites which feed on the nematode. Therefore, it is advocated that Calotropis procera as seed treatment may be a good alternative of nematicides to enhance plant growth parameters and to reduce infection of maize cyst nematode, $H$. zeae on maize.

\section{References}

Bhardwaj, P. and Trivedi, P. C. 1999. Bio pesticides in the management of Heterodera cajani on cowpea. Proceedings of the National Academy of Sciences, India, Section-B. Biological Sciences 69: 343-345.

Christie, J.R. and Perry, V.G. 1951. Removing nematodes from soil. Proceedings of Helminthological Society of Washington 18: 106-08.

Cobb, N. A. (1918). Estimating the nematode population of the soil. U. S. Department of Agriculture, Bureau of Plant Edn. Agr. Tech. Cir 1: 1-48.

Kaushal, K. K., Shrivastava, A. N., Pankaj, Chawla, G. and Singh, K. (2007). Cyst forming nematodes in India- A review. Indian Journal of Nematology 37: 1-7.

Koshy, P. K. and Swarup, G. (1971). Indian Journal of Nematology 1: 106-11.

Meena, K. K., Baheti, B. L., Rathore, B. S. and. Sharma, S. K. 2013. Distribution of maize cyst nematode, Heterodera zeae in different agro-climatic regions of Rajasthan. Indian Journal of Nematology 43: 222-224.

Mehta, S. K., Baheti, B. L., Rathore, B. S. and Nama, C. P. 2015. An effective tool for the management of maize cyst nematode, Heterodera zeae on maize (Zea mays L.). Journal of Biopesticides 8: 62-67.

Saravanapriya, B. and Sivakumar, M. 2005. Management of root-knot nematode Meloidogyne incognita on tomato with botanicals. Natural Product Radiance 4: 158-161.

Srivastava, A. N. and Chawla, G. 2005. Maize cyst nematode, Heterodera zeae a key 
nematode pest of maize and its management. IARI, New Delhi-18.

Umainaheswari and Babu, R. S. 2001. Management of root-knot nematode, $M$. incognita and reniform nematode, Rotylenchulus reniformis on cowpea using Calotropis procera leaf powder.
International Journal of Tropical Plant Diseases 19: 19-24.

Venkatesan, M. and Patel, B.A. 2013. Management of root-knot nematodes in bitter gourd using organic amendments, nematicides and bio-agents. Annals of Plant Protection Sciences 21: 176-223.

\section{How to cite this article:}

Kumhar, R.N., B.L. Baheti and Chandrawat, B.S. 2018. Eco-Friendly Management of Maize Cyst Nematode, Heterodera zeae on Maize by Use of Botanicals. Int.J.Curr.Microbiol.App.Sci. 7(06): 199-204. doi: https://doi.org/10.20546/ijcmas.2018.706.025 